\title{
Lophiosilurus alexandri, a sedentary bottom fish, adjusts its physiological parameters to survive to hypoxia condition.
}

Livia de Assis Porto

Universidade Federal de Minas Gerais

Rafael Magno Costa Melo

Universidade Federal de Minas Gerais

Suzane Lilian Beier

Universidade Federal de Minas Gerais

Ronald Kennedy Luz

Universidade Federal de Minas Gerais

Gisele Cristina Favero ( $\nabla$ giselefav82@yahoo.com.br)

Universidade Federal de Minas Gerais https://orcid.org/0000-0002-0978-9103

\section{Research Article}

Keywords: biochemical variables, blood gas parameters, dissolved oxygen, gill morphology, pacamã

Posted Date: April 2nd, 2021

DOl: https://doi.org/10.21203/rs.3.rs-367925/v1

License: (9) This work is licensed under a Creative Commons Attribution 4.0 International License. Read Full License 


\section{Abstract}

We investigated blood gas, hematological and biochemical parameters and gill morphology and morphometry of Lophiosilurus alexandri juveniles submitted to hypoxia for 48 hours followed by recovery for 48 hours. A total of 48 juveniles $(360.0 \pm 141.6 \mathrm{~g})$ were distributed among eight tanks $(120 \mathrm{~L})$ and subjected to hypoxia condition (water with dissolved oxygen at $2.12 \pm 0.90 \mathrm{mg} \mathrm{L}^{-1}$ ) or normoxia (at 5.60 $\left.\pm 0.31 \mathrm{mg} \mathrm{L}^{-1}\right)$. Blood gas values ( $\mathrm{pH}, \mathrm{PvCO}_{2}, \mathrm{PvO}_{2}, \mathrm{sO}_{2}, \mathrm{HCO}_{3}{ }^{-}, \mathrm{stHCO}_{3}{ }^{-}$and base excess) in hypoxia were significantly different from normoxia, while lactate and the electrolytes $\left(\mathrm{K}^{+}, \mathrm{Na}^{+}, \mathrm{Cl}^{-}, \mathrm{Ca}^{2+}\right.$ and $\mathrm{HCO}_{3}{ }^{-}$) there was no significant change among treatments. The erythrocytes differed significantly between hypoxia and normoxia at $24 \mathrm{~h}$ of recovery, while for hemoglobin and hematocrit there were no significant differences. There was a significant difference in glucose, triglycerides, and cholesterol for both normoxia and hypoxia, while plasma protein remained unchanged. All gill components (epithelial cells, erythrocytes, pillar cells, mucus cells, chloride cells, undifferentiated cells, and blood capillary lumen) differed significantly between hypoxia and normoxia. A reduction in the length of the primary lamella was observed in the hypoxia and recovery treatments, when compared to normoxia. The secondary branchial lamella showed no significant difference for both treatments. In general, juveniles of L. alexandri adapted well to hypoxia exposure for $48 \mathrm{~h}$, as they were able to adjust most of their physiological variables to survive this stress condition and return to normoxia within $48 \mathrm{~h}$.

\section{Introduction}

The stress response of fish occurs through neuroendocrine control in a way very similar to that of mammals. Fish have a cephalic kidney and chromaffin and interrenal cells as structures homologous to the adrenal gland of mammals, and which perform the function of secreting circulating catecholamines (epinephrine and norepinephrine) and corticosteroids, such as cortisol (Barton 2000; Gallo and Civinini 2003). Stress presents three responses: the primary response, also known as the alarm response, is accompanied by high concentrations of catecholamines and corticosteroids in the plasma; the secondary response is related to increased blood hormonal levels, which promote increased heart rate and higher oxygen consumption; the tertiary response begins with the exhaustion of the organism, which causes a decrease in productive and reproductive performance and exposes the animal to various pathogens (Barton 2002; Lima et al. 2006; Wendelaar Bonga 1997).

Fish can experience several factors that are considered stressors in captivity, such as high confinement densities (Long et al. 2019; Refaey et al. 2018; Yarahmadi et al. 2016), handling and transportation (Jerez-Cepa et al. 2019; Sena et al. 2016) and changes in water quality (Lankford et al. 2003; Zhang et al. 2015). These stressors generate physiological disorders, which cause discomfort, impair well-being and potentially compromise survival. Thus, to maintain and restore body homeostasis, a stressed animal consumes energy due to breathing, locomotion and tissue repair, instead of using it for growth, reproduction, food intake and physiological status (Schreck and Tort 2016). 
Low oxygen levels are common in farming environments yet, according to Gilmore et al. (2018), hypoxia can occur when dissolved oxygen (DO) in the water falls below a level physiologically suitable for fish, which affects their survival (Abdel-Tawwab et al. 2019; Cook and Herbert 2012; Fitzgibbon et al. 2007; Xiao 2015). Thus, hypoxia can impair fish growth (Abdel Tawwab et al. 2019; Magnoni et al. 2018) and reproduction (Konkal and Ganesh 2020; Lai et al. 2019; Schreck 2010), as well as their immune system (Abdel Tawwab et al. 2019; Baldissera et al. 2018). In this sense, studies have revealed the effects of hypoxia on blood, biochemical and immunological parameters, which are good indicators of animals in inadequate conditions, for species such as Prochilodus nigricans (Val et al. 2015), Micropterus salmoides (Yang et al. 2017), Sparus aurata (Araújo-Luna et al. 2018), Oreochromis niloticus (Li et al. 2018) and Lophiosilurus alexandri (Baldissera et al. 2018).

Pacamã, Lophiosilurus alexandri, is a Brazilian freshwater fish species endemic to the São Francisco River basin (Shibata 2003) that has excellent quality meat and is among regional species with high commercial value (Luz and Santos 2008). The species shows sedentary behavior and a preference for lentic environments in sandy or rocky regions (Travassos 1959). Due to its peculiar characteristics, however, it remains to be seen how this species responds physiologically to decreased water dissolved oxygen concentrations in the captive environment. Thus, the aim of this study was to evaluate the responses of blood gas, hematological and biochemical parameters, as well as gill morphology, of $L$. alexandri juveniles submitted to hypoxia and subsequent recovery.

\section{Material And Methods}

This study was conducted at Laboratório de Aquacultura (LAQUA) of the Universidade Federal de Minas Gerais (UFMG), Belo Horizonte, Minas Gerais, Brazil, and was approved by the Animal Ethics and Welfare Committee of UFMG (protocol number: 61/2019).

\subsection{Fish and experimental conditions}

A total of 48 juveniles $(360.0 \pm 141.6 \mathrm{~g}, 26.6 \pm 3.0 \mathrm{~cm})$ were distributed among eight tanks $(120 \mathrm{~L}$; six animals per tank) in a recirculating aquaculture system (RAS) with biological and mechanical filters, where they were acclimatized for 15 days. Fish were fed until apparent satiety twice a day ( 8 am and 4 $\mathrm{pm}$ ) with a commercial extruded diet (38\% of crude protein). The water quality during acclimatization remained at: dissolved oxygen (DO) $5.10 \pm 0.56 \mathrm{mg} \mathrm{L}^{-1}$; temperature $28.9 \pm 0.28^{\circ} \mathrm{C} ; \mathrm{pH} 7.04 \pm 0.11$; and total ammonia $0.05 \pm 0.01 \mathrm{mmol} \mathrm{L}^{-1}$. Dissolved oxygen concentration and temperature were measured using a digital oximeter (model EcoSense - YSI DO200A), pH was measured using a peagameter (model KASVI - K39) and total ammonia using a commercial kit (LabconTest $\left.{ }^{\circledR}\right)$.

The water flow and artificial aeration of four of the tanks were interrupted to decrease the DO concentration and promote a condition of hypoxia (hypoxia treatment). After reaching a DO concentration of about $2.0 \mathrm{mg} \mathrm{L}^{-1}$, the water flow was turned on again, but kept low, thus maintaining a DO concentration of $2.12 \pm 0.90 \mathrm{mg} \mathrm{L}^{-1}$ for $48 \mathrm{~h}$. The other four other tanks were maintained at normoxia 
(normoxia treatment) with stable water flow and aeration and DO maintained at $5.60 \pm 0.31 \mathrm{mg} \mathrm{L}^{-1}$. After $48 \mathrm{~h}$, water flow and aeration were restored to the hypoxia tanks and the DO was maintained at $5.30 \pm$ $0.47 \mathrm{mg} \mathrm{L}^{-1}$, similar to that of the normoxia tanks. The animals remained in these conditions for another $48 \mathrm{~h}$, for a total experiment time of $96 \mathrm{~h}$. During the experiment, the animals were fed twice a day until apparent satiety with the same commercial diet used during acclimatization.

\subsection{Blood sampling and analysis}

Six fish (from the same tank) of the hypoxia treatment were collected at 24 and $48 \mathrm{~h}$ of hypoxia and at 24 and $48 \mathrm{~h}$ of recovery, while six fish (from the same tank) of the normoxia treatment were collected at the same times. Two blood samples were collected from each fish, while contained in an appropriate damp cloth, by caudal venipuncture with ventral access using heparinized syringes. From the first sample, 300 $\mu \mathrm{l}$ of blood was placed in microtubes on ice for blood gas analysis and subsequent determination of the following parameters: $\mathrm{pH}, \mathrm{PvCO}_{2}$ (partial pressure of carbon dioxide), $\mathrm{PvO}_{2}$ (partial pressure of oxygen), $\mathrm{SO}_{2}$ (oxygen saturation), $\mathrm{CLac}$ (lactate), $\mathrm{K}^{+}, \mathrm{Na}^{+}, \mathrm{Cl}^{-}, \mathrm{Ca}^{2+}, \mathrm{HCO}_{3}{ }^{-}$(bicarbonate), $\mathrm{stHCO}_{3}{ }^{-}$(standard bicarbonate) and $\mathrm{BE}$ (base excess). These analyses were performed using a blood gas analyzer (ABL800 BASIC-Radiometer $\left.{ }^{\circledR}\right)$, with water temperature and oxygen concentration being corrected by the equipment, according to the experimental treatments.

From the second blood sample, approximately one milliliter of blood was collected to assess hematological and biochemical parameters. Hematocrit (\%) was determined using the microhematocrit technique (Goldenfarb et al., 1971); plasma protein was measured by refractometry (portable refractometer, RHC 200-ATC, Huake Instrument Co., Ltd); and hemoglobin concentration was determined by spectrophotometry (Biochrom Libra S22) with the aid of a commercial kit (Ref. K023-1 QUIBASA Ltda. Bioclin). Erythrocyte counts were performed within $24 \mathrm{~h}$ after sampling using a hemocytometer and an optical microscope with $400 \mathrm{X}$ magnification. The remaining blood was centrifuged for $10 \mathrm{~min}$ at 4000 rpm for plasma separation and subsequent determination of glucose, triglycerides and cholesterol concentrations using an enzymatic-colorimetric method (Trinder reaction). All biochemical parameters were analyzed with commercial kits (Bioclin $\AA$ - Belo Horizonte, Brazil - www.bioclin.com) and read with a spectrophotometer (Biochrom Libra S22).

\subsection{Gill morphology and morphometry}

The same animals used for blood sampling were euthanized ( $285 \mathrm{mg} \mathrm{L}^{-1}$ eugenol) for gill collection. For histological analysis, the 2nd gill arch of each animal was fixed in Bouin solution for $24 \mathrm{~h}$, embedded in paraffin, sectioned at $5 \mu \mathrm{m}$ thickness and stained with hematoxylin-eosin. The main structures in the primary and secondary gill lamellae were quantified using 40 histological fields from four individuals analyzed per treatment ( 24 and $48 \mathrm{~h}$ of hypoxia and 24 and $48 \mathrm{~h}$ of recovery for hypoxia treatment and same times for normoxia treatment). The relative proportion of the gill components (epithelial cell, erythrocytes, pillar cells, mucous cells, chloride cells, undifferentiated cells, and blood capillary lumen) were determined using a grid containing 560 intersection points overlaying each field and Image 1.52 software. Blank spaces and artefacts were excluded from the counts. To measure the diameter of the 
primary and secondary lamellae of the gills, 40 measurements extracted from four fish per group (10 measurements from each animal) were used, of which four treatments and one initial control. This measurement was performed using the AxioVision SE64 software coupled to an Axioplan 2 microscope (Zeiss).

\subsection{Statistical analysis}

All blood data were analyzed (SigmaPlot ${ }^{\circledR}$ Software, version 11.0) in a completely randomized design using a one-way ANOVA, to compare treatments over sampling time and the t-test to compare treatments (normoxia and hypoxia) at each time. Normality and homoscedasticity of the data were evaluated by the Shapiro-Wilk and Levene tests, respectively, followed by Tukey post-hoc test with $5 \%$ probability. Data are presented as mean and standard error (SE). Data for the relative proportion of gill structures were subjected to Kruskal-Wallis statistical analysis followed by Dunn post-hoc test with $5 \%$ probability $(\mathrm{P}<$ 0.05).

\section{Results}

\subsection{Blood gas parameters}

Results for blood gas parameters are shown in Table 1. Values for $\mathrm{pH}$ did not differ significantly among sampling times for the normoxia $(P=0.153)$ and hypoxia treatments $(P=0.052)$. However, there was a significant difference between treatments at $24 \mathrm{~h}$ of recovery, with animals submitted to hypoxia showing higher blood $\mathrm{pH}(P=0.010)$. 
Table 1

Blood gas values of Lophiosilurus alexandri. Variables measured: potential of hydrogen ( $\mathrm{pH})$, partial carbon dioxide pressure $\left(\mathrm{PvCO}_{2}-\mathrm{mmHg}\right)$, partial oxygen pressure $\left(\mathrm{PvO}_{2}-\mathrm{mmHg}\right)$, oxygen saturation $\left(\mathrm{sO}_{2}\right)-\%$ ), lactate $\left(\mathrm{cLac}-\mathrm{mmol} \mathrm{L}^{-1}\right)$, potassium $\left(\mathrm{K}^{+}-\mathrm{mmol} \mathrm{L}^{-1}\right)$, sodium $\left(\mathrm{Na}^{+}-\mathrm{mmol} \mathrm{L}^{-1}\right)$, chloride $\left(\mathrm{Cl}^{-}\right.$ $\mathrm{mmol} \mathrm{L}-1)$, calcium $\left(\mathrm{Ca}^{2+}-\mathrm{mmol} \mathrm{L}^{-1}\right)$, bicarbonate $\left(\mathrm{HCO}_{3}{ }^{-}-\mathrm{mmol} \mathrm{L}{ }^{-1}\right)$, standard bicarbonate $\left(\mathrm{stHCO}_{3}{ }^{-}\right.$$\mathrm{mmol} \mathrm{L}^{-1}$ ) and base excess $\left(\mathrm{BE}-\mathrm{mmol} \mathrm{L}^{-1}\right)$.

\begin{tabular}{|c|c|c|c|c|c|}
\hline \multirow[t]{3}{*}{ Variables } & & \multicolumn{4}{|l|}{ Time } \\
\hline & & $24 \mathrm{~h}$ & $48 h$ & $24 \mathrm{~h}$ & $48 \mathrm{~h}$ \\
\hline & & Hypoxia & Hypoxia & Recovery & Recovery \\
\hline \multirow[t]{2}{*}{$\mathrm{pH}$} & Normoxia & $7.47 \pm 0.02 \mathrm{Aa}$ & $7.42 \pm 0.03 \mathrm{Aa}$ & $7.43 \pm 0.03 \mathrm{Ab}$ & $7.37 \pm 0.02 \mathrm{Aa}$ \\
\hline & Hypoxia & $7.49 \pm 0.03 \mathrm{Aa}$ & $7.46 \pm 0.02 \mathrm{Aa}$ & $7.56 \pm 0.02 \mathrm{Aa}$ & $7.44 \pm 0.03 \mathrm{Aa}$ \\
\hline \multirow[t]{2}{*}{$\mathrm{PvCO}_{2}$} & Normoxia & $4.60 \pm 0.32 \mathrm{Aa}$ & $5.61 \pm 0.26 \mathrm{Aa}$ & $5.33 \pm 0.23 \mathrm{Aa}$ & $5.48 \pm 0.51 \mathrm{Aa}$ \\
\hline & Hypoxia & $5.26 \pm 0.27 \mathrm{Aa}$ & $4.83 \pm 0.12 \mathrm{ABa}$ & $4.05 \pm 0.27 \mathrm{Ba}$ & $5.73 \pm 0.36 \mathrm{Aa}$ \\
\hline \multirow[t]{2}{*}{$\mathrm{PvO}_{2}$} & Normoxia & $17.38 \pm 2.54 \mathrm{Aa}$ & \multirow{2}{*}{$\begin{array}{l}15.94 \pm 2.22 \\
\mathrm{ABa} \\
19.73 \pm 3.34 \mathrm{Aa}\end{array}$} & \multirow{2}{*}{$\begin{array}{l}11.90 \pm 0.73 \\
\mathrm{ABa} \\
12.10 \pm 2.16 \mathrm{Aa}\end{array}$} & $8.27 \pm 1.70 \mathrm{Bb}$ \\
\hline & Hypoxia & $14.68 \pm 1.10 \mathrm{Ab}$ & & & $12.48 \pm 2.35 \mathrm{Aa}$ \\
\hline \multirow[t]{2}{*}{$\mathrm{sO}_{2}$} & Normoxia & $41.47 \pm 6.25 \mathrm{Aa}$ & $41.33 \pm 7.31 \mathrm{Aa}$ & $23.73 \pm 2.71 \mathrm{Ab}$ & \multirow{2}{*}{$\begin{array}{l}37.95 \pm 13.14 \\
\mathrm{Aa} \\
38.73 \pm 5.18 \mathrm{Aa}\end{array}$} \\
\hline & Hypoxia & $41.92 \pm 5.00 \mathrm{Aa}$ & $63.67 \pm 5.97 \mathrm{Aa}$ & $54.77 \pm 9.42 \mathrm{Aa}$ & \\
\hline \multirow[t]{2}{*}{ cLac } & Normoxia & $0.12 \pm 0.05 \mathrm{Aa}$ & $0.07 \pm 0.03 \mathrm{Aa}$ & $0.08 \pm 0.03 \mathrm{Aa}$ & $0.17 \pm 0.03 \mathrm{Aa}$ \\
\hline & Hypoxia & $0.05 \pm 0.03 \mathrm{Aa}$ & $0.05 \pm 0.05 \mathrm{Aa}$ & $0.00 \pm 0.00 \mathrm{Aa}$ & $0.13 \pm 0.05 \mathrm{Aa}$ \\
\hline \multirow[t]{2}{*}{$\mathrm{K}^{+}$} & Normoxia & $3.80 \pm 0.16 \mathrm{ABa}$ & $3.87 \pm 0.09 \mathrm{ABa}$ & $3.58 \pm 0.11 \mathrm{Ba}$ & $4.32 \pm 0.21 \mathrm{Aa}$ \\
\hline & Hypoxia & $3.94 \pm 0.30 \mathrm{Aa}$ & $3.42 \pm 0.19 \mathrm{Aa}$ & $3.82 \pm 0.23 \mathrm{Aa}$ & $4.20 \pm 0.22 \mathrm{Aa}$ \\
\hline \multirow[t]{2}{*}{$\mathrm{Na}^{+}$} & & $\begin{array}{l}147.67 \pm 8.12 \\
\mathrm{Aa}\end{array}$ & $\begin{array}{l}146.00 \pm 4.45 \\
\mathrm{Aa}\end{array}$ & $\begin{array}{l}138.67 \pm 3.07 \\
\mathrm{Aa}\end{array}$ & $\begin{array}{l}149.83 \pm 5.00 \\
\mathrm{Aa}\end{array}$ \\
\hline & הםנהסקיר & $\begin{array}{l}139.40 \pm 4.34 \\
\mathrm{Aa}\end{array}$ & $\begin{array}{l}140.00 \pm 6.29 \\
\mathrm{Aa}\end{array}$ & $\begin{array}{l}143.00 \pm 6.69 \\
\mathrm{Aa}\end{array}$ & $\begin{array}{l}142.00 \pm 6.21 \\
\mathrm{Aa}\end{array}$ \\
\hline \multirow[t]{2}{*}{$\mathrm{Cl}^{-}$} & Normoxia & $\begin{array}{l}143.33 \pm 8.50 \\
\mathrm{Aa}\end{array}$ & $\begin{array}{l}143.33 \pm 4.66 \\
\mathrm{Aa}\end{array}$ & $\begin{array}{l}133.67 \pm 3.61 \\
\text { Aa }\end{array}$ & $\begin{array}{l}148.33 \pm 5.10 \\
\text { Aa }\end{array}$ \\
\hline & 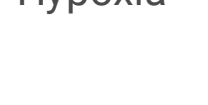 & $\begin{array}{l}132.00 \pm 3.19 \\
\mathrm{Aa}\end{array}$ & $\begin{array}{l}133.80 \pm 6.55 \\
\mathrm{Aa}\end{array}$ & $\begin{array}{l}134.60 \pm 5.16 \\
\mathrm{Aa}\end{array}$ & $\begin{array}{l}132.75 \pm 4.46 \\
\text { Aa }\end{array}$ \\
\hline
\end{tabular}

Capital letters (in row) indicate significant differences between normoxia or hypoxia treatment over the sampling time. Lowercase letters (in the column) compare normoxia and hypoxia treatments within the same sampling time. Values are expressed as means \pm standard error (SE). All comparisons were statistically different at $P<0.05$. 


\begin{tabular}{|c|c|c|c|c|c|}
\hline \multicolumn{2}{|l|}{ Variables } & \multicolumn{4}{|l|}{ Time } \\
\hline & & \multirow{2}{*}{$\begin{array}{l}24 \text { h } \\
\text { Hypoxia }\end{array}$} & \multirow{2}{*}{$\begin{array}{l}48 \mathrm{~h} \\
\text { Hypoxia }\end{array}$} & \multirow{2}{*}{$\begin{array}{l}24 \mathrm{~h} \\
\text { Recovery }\end{array}$} & \multirow{2}{*}{$\begin{array}{l}48 \mathrm{~h} \\
\text { Recovery }\end{array}$} \\
\hline & & & & & \\
\hline \multirow[t]{2}{*}{$\mathrm{Ca}^{2+}$} & Normoxia & $1.12 \pm 0.10 \mathrm{Aa}$ & $0.91 \pm 0.10 \mathrm{Aa}$ & $0.82 \pm 0.07 \mathrm{Aa}$ & $1.01 \pm 0.14 \mathrm{Aa}$ \\
\hline & Hypoxia & $1.06 \pm 0.04 \mathrm{Aa}$ & $0.82 \pm 0.03 \mathrm{ABa}$ & $0.70 \pm 0.05 \mathrm{Ba}$ & $0.97 \pm 0.13 \mathrm{Aa}$ \\
\hline \multirow[t]{2}{*}{$\mathrm{HCO}_{3}^{-}$} & Normoxia & $3.52 \pm 0.14 \mathrm{Bb}$ & $4.22 \pm 0.20 \mathrm{Aa}$ & $3.92 \pm 0.18 \mathrm{ABa}$ & $3.62 \pm 0.16 \mathrm{ABb}$ \\
\hline & Hypoxia & $4.58 \pm 0.30 \mathrm{Aa}$ & $3.67 \pm 0.35 \mathrm{Aa}$ & $3.80 \pm 0.08 \mathrm{Aa}$ & $4.38 \pm 0.25 \mathrm{Aa}$ \\
\hline \multirow[t]{2}{*}{$\mathrm{stHCO}_{3}^{-}$} & Normoxia & $7.47 \pm 0.20 \mathrm{Ab}$ & $8.10 \pm 0.52 \mathrm{Aa}$ & $7.40 \pm 0.38 \mathrm{Aa}$ & $6.89 \pm 0.20 \mathrm{Ab}$ \\
\hline & Hypoxia & $8.60 \pm 0.50 \mathrm{Aa}$ & $7.08 \pm 0.53 \mathrm{Aa}$ & $7.78 \pm 0.19 \mathrm{Aa}$ & $7.88 \pm 0.33 \mathrm{Aa}$ \\
\hline \multirow[t]{2}{*}{$\mathrm{BE}$} & Normoxia & $-22.35 \pm 0.23 \mathrm{Ab}$ & $-21.67 \pm 0.55 \mathrm{Aa}$ & $-22.13 \pm 0.54 \mathrm{Aa}$ & $-23.32 \pm 0.27 \mathrm{Ab}$ \\
\hline & Hypoxia & $-20.60 \pm 0.72 \mathrm{Aa}$ & $-22.90 \pm 0.88 \mathrm{Aa}$ & $-21.56 \pm 0.22 \mathrm{Aa}$ & $-21.48 \pm 0.55 \mathrm{Aa}$ \\
\hline
\end{tabular}

Significant differences in $\mathrm{PvCO}_{2}$ were observed among sampling times only for the hypoxia treatment, with it being lowest at $24 \mathrm{~h}$ of recovery $(P=0.008)$, compared to other sampling times.

Values for $\mathrm{PvO}_{2}$ did not differ significantly among sampling times for the hypoxia treatment $(P=0.150)$; however, a significantly higher value was observed at $24 \mathrm{~h}$ of hypoxia for the normoxia treatment compared to $48 \mathrm{~h}$ of recovery $(P=0.111)$. Fish submitted to hypoxia had significantly lower $\mathrm{PvO}_{2}$ at $24 \mathrm{~h}$ of hypoxia $(P=0.355)$ and significantly higher $\mathrm{PvO}_{2}$ at $48 \mathrm{~h}$ of recovery $(P=0.111)$ in relation to normoxia. The only significant difference for $\mathrm{SO}_{2}$ was found between treatments (normoxia and hypoxia) at $24 \mathrm{~h}$ of recovery $(P=0.026)$, in which there was a higher percentage of $\mathrm{SO}_{2}$ in the hypoxia treatment.

No significant differences were observed over time for either of the treatments nor between them for lactate (cLac) $(P>0.05)$ and to electrolytes $\mathrm{K}^{+}(P>0.05) \mathrm{Na}^{+}(P>0,05)$ and $\mathrm{Cl}^{-}(P>0.05)$. There was a decrease in $\mathrm{Ca}^{2+}$ levels in hypoxia treatment at $24 \mathrm{~h}$ of recovery $(P=0.004)$, when compared to $24 \mathrm{~h}$ of hypoxia and $48 \mathrm{~h}$ of recovery. For $\mathrm{HCO}_{3}{ }^{-}$there were significant differences between normoxia and hypoxia treatments at $24 \mathrm{~h}$ of hypoxia $(P=0.009)$ and $48 \mathrm{~h}$ of recovery $(P=0.042)$, in which the concentrations of $\mathrm{HCO}_{3}{ }^{-}$were higher in the hypoxia treatment. In relation to the sampling times, higher concentrations of $\mathrm{HCO}_{3}{ }^{-}$were observed at $48 \mathrm{~h}$ of hypoxia $(P=0.198)$ and at $24 \mathrm{~h}(P=0.640)$ and $48 \mathrm{~h}$ $(P=0.042)$ of recovery. 
Values for $\mathrm{stHCO}_{3}{ }^{-}$differed significantly among treatments at $24 \mathrm{~h}$ of hypoxia and $48 \mathrm{~h}$ of recovery, in which there was an increase in $\mathrm{stHCO}_{3}{ }^{-}$concentrations in hypoxia treatment at both sampling times, compared to the normoxia treatment $(P=0.051$, at $24 \mathrm{~h}$ of hypoxia and $P=0.026$, at $48 \mathrm{~h}$ of recovery).

Base excess (BE) remained constant over sampling times for normoxia $(P=0.075)$ and hypoxia $(P=$ $0.156)$ treatments. Values for BE were significantly higher for the hypoxia treatment at $24 \mathrm{~h}$ of hypoxia ( $P$ $=0.033)$ and $48 \mathrm{~h}$ of recovery $(P=0.014)$, compared to the normoxia treatment.

\subsection{Hematological and biochemical parameters}

Erythrocytes (Fig. 1A) did not differ significantly among sampling times for the normoxia treatment $(P>$ $0.05)$, but there was a significantly lower count for the hypoxia treatment at $48 \mathrm{~h}$ of hypoxia $(P=0.015)$. The hypoxia treatment had a significantly higher erythrocytes count at $24 \mathrm{~h}$ of recovery than normoxia treatment $(P=0.036)$.

Hemoglobin concentrations (Fig. 1B) did not differ significantly among sampling times for both treatments $(P>0.05)$ or between treatments at the different sampling times $(P>0.05)$. Hematocrit (Fig. 1C) differed significantly among sampling times for the hypoxia treatment, with it decreasing over time $(P=0.015)$, while it did not differ significantly among sampling times for the normoxia treatment $(P$ $>0.05)$. Hematocrit did not differ among treatments in each sampling time $(P>0.05)$.

Plasma glucose (Fig. 2A) for normoxia treatment differed significantly among sampling times $(\mathrm{P}=$ 0.007 ), with it being lowest at the time corresponding to $24 \mathrm{~h}$ hypoxia. The hypoxia treatment also differed significantly among times, with it being highest at $48 \mathrm{~h}$ of recovery $(P=0.004)$. Glucose levels for hypoxia treatment at $48 \mathrm{~h}$ of hypoxia and $24 \mathrm{~h}$ of recovery were significantly lower than that for normoxia $(P=0.006)$, however, at $24 \mathrm{~h}$ of hypoxia and $48 \mathrm{~h}$ of recovery the treatments did not differ significantly $(P$ $>0.05)$.

The levels of triglycerides (Fig. 2B) differed between the sampling times for normoxia treatment, with the lowest values corresponding to $24 \mathrm{~h}$ of hypoxia $(P<0.001)$, and $24(P=0,160)$, and $48 \mathrm{~h}$ of recovery $(P=$ 0.281). Hypoxia treatment did not show a significant difference in triglycerides between sampling times but had lower levels in $48 \mathrm{~h}$ of hypoxia $(P=0.003)$ compared to normoxia treatment.

Cholesterol (Fig. 2C) differed completely over the sampling times for both treatments. For hypoxia treatment, the lowest level of cholesterol was found at $24 \mathrm{~h}$ of recovery $(P=0.020)$ and the highest value at $24 \mathrm{~h}$ of hypoxia $(P=0.022)$. The normoxia treatment also differed between sampling times, with the lowest value at $24 \mathrm{~h}$ of hypoxia $(P=0.016)$. Plasma protein (Fig. 2D) did not show difference between treatments at the same sampling times, however for the normoxia treatment there was a decrease in plasma protein at $24 \mathrm{~h}$ of recovery $(P=0.818)$, compared to normoxia in the other sampling times.

\subsection{Gill lamellar morphology and morphometry}


The structural components analysed in gills of juveniles of $L$. alexandri during the experiment are shown in Fig. 3. A higher proportion of epithelial cells was observed at $24 \mathrm{~h}$ of hypoxia compared to normoxia and the other sampling times, while there was a lower proportion at $48 \mathrm{~h}$ of recovery. The percentage of erythrocytes in gill increased during 24 and $48 \mathrm{~h}$ of hypoxia and during at 24 and $48 \mathrm{~h}$ of recovery when compared to normoxia treatment, showing the highest erythrocyte count at $24 \mathrm{~h}$ of recovery (Table 2 ).

Table 2

Relative proportion (\%) of structural components and lamellar diameter $(\mu \mathrm{m})$ of gills in juveniles of $L$. alexandri submitted to hypoxia.

\begin{tabular}{|c|c|c|c|c|c|c|}
\hline \multirow[t]{2}{*}{ Gill structures } & \multirow[t]{2}{*}{ Normoxia } & \multicolumn{2}{|l|}{ Hypoxia } & \multicolumn{2}{|l|}{ Recovery } & \multirow{2}{*}{$\begin{array}{l}P \text { - } \\
\text { value }\end{array}$} \\
\hline & & $24 \mathrm{~h}$ & $48 \mathrm{~h}$ & $24 \mathrm{~h}$ & $48 \mathrm{~h}$ & \\
\hline Epithelial cells & $22,0 \pm 0,7^{b}$ & $27,0 \pm 0,5^{a}$ & $23,0 \pm 0,4^{\mathrm{b}}$ & $24,0 \pm 0,3^{b}$ & $12,0 \pm 0,3^{c}$ & $\begin{array}{l}< \\
0.001\end{array}$ \\
\hline Erythrocytes & $27,0 \pm 0,6^{d}$ & $36,0 \pm 0,7^{c}$ & $45,0 \pm 0,7^{b}$ & $75,0 \pm 0,4^{\mathrm{a}}$ & $50,0 \pm 0,3^{b}$ & $<.001$ \\
\hline Pillar cells & $6,0 \pm 0,2^{a}$ & $4,0 \pm 0,1^{b}$ & $5,0 \pm 0,1^{b}$ & $4,0 \pm 0,1^{b}$ & $1,0 \pm 0,1^{c}$ & $\begin{array}{l}< \\
0.001\end{array}$ \\
\hline Mucous cells & $8,0 \pm 0,3^{a}$ & $7,0 \pm 0,1^{b}$ & $9,0 \pm 0,2^{\mathrm{a}}$ & $8,0 \pm 0,2^{\mathrm{ab}}$ & $4,0 \pm 0,1^{c}$ & $\begin{array}{l}< \\
0.001\end{array}$ \\
\hline Chloride cells & $2,0 \pm 0,1^{a}$ & $1,0 \pm 0,1^{b}$ & $7,0 \pm 0,4^{\mathrm{a}}$ & $1,0 \pm 0,1^{b}$ & $1,0 \pm 0,1^{b}$ & $<.001$ \\
\hline $\begin{array}{l}\text { Undifferentiated } \\
\text { cells }\end{array}$ & $11,0 \pm 0,6^{\mathrm{a}}$ & $13,0 \pm 1,0^{a}$ & $9,0 \pm 0,3^{a}$ & $4,0 \pm 0,1^{b}$ & $4,0 \pm 0,1^{b}$ & $\begin{array}{l}< \\
0.001\end{array}$ \\
\hline $\begin{array}{l}\text { Blood capillary } \\
\text { lumen }\end{array}$ & $24,0 \pm 1,6^{a}$ & $12,0 \pm 0,6^{b}$ & $2,0 \pm 0,1^{c}$ & $4,0 \pm 0,1^{c}$ & $28,0 \pm 0,3^{a}$ & $<0.001$ \\
\hline Primary lamellae & $\begin{array}{l}58.14 \pm \\
1.82^{\mathrm{a}}\end{array}$ & $\begin{array}{l}43.83 \pm \\
1.93^{\mathrm{b}}\end{array}$ & $\begin{array}{l}41.60 \pm \\
2.17^{\mathrm{b}}\end{array}$ & $\begin{array}{l}45.70 \pm \\
1.83^{\mathrm{b}}\end{array}$ & $\begin{array}{l}42.10 \pm \\
1.20^{\mathrm{b}}\end{array}$ & $<.001$ \\
\hline $\begin{array}{l}\text { Secondary } \\
\text { lamellae }\end{array}$ & $\begin{array}{l}21.91 \pm \\
0.62^{\mathrm{ab}}\end{array}$ & $\begin{array}{l}20.87 \pm \\
0.63^{b}\end{array}$ & $\begin{array}{l}28.60 \pm \\
2.12^{\mathrm{a}}\end{array}$ & $\begin{array}{l}23.65 \pm \\
0.74^{\mathrm{a}}\end{array}$ & $\begin{array}{l}20.72 \pm \\
0.73^{b}\end{array}$ & $\begin{array}{l}< \\
0.001\end{array}$ \\
\hline
\end{tabular}

Gills of the hypoxia treatment had a significantly lower percentage of pillar cells at 24 and $48 \mathrm{~h}$ of hypoxia and at 24 and $48 \mathrm{~h}$ of recovery, compared to normoxia treatment, with the lowest percentage at $48 \mathrm{~h}$ of recovery. Fewer mucous cells were observed for the hypoxia treatment at $24 \mathrm{~h}$ of hypoxia and at $48 \mathrm{~h}$ of recovery, compared to normoxia treatment. The percentage of chloride cells for hypoxia treatment 
at $24 \mathrm{~h}$ of hypoxia and 24 and $48 \mathrm{~h}$ of recovery was lower compared to normoxia and $48 \mathrm{~h}$ of hypoxia (Table 2).

The proportion of undifferentiated cells was lower at 24 and $48 \mathrm{~h}$ of recovery, when compared to hypoxia times and normoxia treatment. The percentage of blood capillary lumen for hypoxia treatment was lower at 24 and $48 \mathrm{~h}$ of hypoxia and at $24 \mathrm{~h}$ of recovery compared to normoxia treatment; however, at $48 \mathrm{~h}$ of recovery, no significant difference was observed in relation to normoxia (Table 2). A reduction in the length of the primary lamella was observed in the hypoxia and recovery treatments, when compared to the control group. The secondary branchial lamella showed no significant difference $(P>0.05)$ for both treatments and over the sampling times (Table 2).

\section{Discussion}

Our study aimed to evaluate the effects of hypoxia during 24 and $48 \mathrm{~h}$, on blood gas parameters, hematological, biochemical and possible changes in gill morphology of Lophiosilurus alexandri. Mortality was not observed at 24 and $48 \mathrm{~h}$ of hypoxia or at 24 and $48 \mathrm{~h}$ of recovery, similar to the study by Mahfouz et al. (2015) for Oreochromis niloticus exposed to short ( $24 \mathrm{~h}$ ) and prolonged (30 days) hypoxia, and Mattioli et al. (2019) for $L$. alexandri juveniles submitted to air exposure for $30 \mathrm{~min}$. In a more recent study of the same species, Baldissera et al. (2020) observed only one case of mortality after exposure to hypoxia for $72 \mathrm{~h}$. According to Richards (2009), conditions of hypoxia allow animals to reveal their adaptive responses, such as enhanced survival due to changes in the expression of some genes by fish exposed to long-term hypoxia (more than a few hours).

In general, the present study found that the pacamã juveniles to reveal adaptive responses to hypoxia, with few changes in blood gas, hematological and biochemical parameters, and with just slight changes in gill morphology without remarkable histopathological alterations. Lophiosilurus alexandri is a species of sedentary behavior and low locomotor activity that lives at the bottom of rivers in its natural environment. Like what Lays et al. (2009) found with the sedentary species Anarhichas minor, conditions of hypoxia did not alter the behavior of $L$. alexandri juveniles in our study and the fish remained calm at the bottom of the tanks throughout the experiment.

As observed in blood gas parameters, there was an increase in blood $\mathrm{pH}$ values in the treatment submitted to hypoxia at period of $24 \mathrm{~h}$ of recovery, compared to normoxia. In addition, an increase in bicarbonate $\left(\mathrm{HCO}_{3}{ }^{-}\right.$and $\left.\mathrm{stHCO}_{3}{ }^{-}\right)$and $\mathrm{BE}$ values were observed at $24 \mathrm{~h}$ of hypoxia and $48 \mathrm{~h}$ of recovery. According to Joyce et al. (2015), these changes may represent strategies for the prevention of blood acidemia, which could lead to respiratory and metabolic acidosis, as was observed by Mattioli et al. (2019) for pacamã juveniles submitted to air exposure. Base excess (BE) alterations may be related to the maintenance of the acid-base balance of the internal environment and are of great physiological and biochemical importance, since the activities of cellular enzymes and electrolytic exchanges and maintenance of the structural state of the proteins in organisms are deeply influenced by small changes 
in blood pH (Macari 1994). Blood $\mathrm{PvO}_{2}$ for the hypoxia treatment decreased at $24 \mathrm{~h}$ of hypoxia, compared to the normoxia treatment, however, this variable quickly returned to normal levels at $24 \mathrm{~h}$ of recovery.

The concentrations of $\mathrm{K}^{+}, \mathrm{Na}^{+}, \mathrm{Cl}^{-}$and $\mathrm{Ca}^{2+}$ ions in hypoxia treatment did not show significant differences during hypoxia nor during recovery, showing that there were no electrolytic changes in $L$. alexandri juveniles. This finding differs from that of Mattioli et al. (2019) with pacamã juveniles subjected to air exposure, where responses such as acidosis and osmotic stress were found. However, juveniles of 0 . niloticus submitted to transport did not show changes in $\mathrm{Ca}^{2+}$ ion levels (Moreira et al. 2015). lonic homeostasis is essential to ensure proper cell function (Hwang et al. 2011), and consequences of routine aquaculture management can generate stress in different species and, thereby, affect ionic regulation in fish (Ashley 2007).

According to Fazio et al. (2013), hematological parameters can be used to determine the physiological status of fish, water quality and other important variables. Hypoxia did not influence erythrocyte counts, as well as hemoglobin and hematocrit, of the $L$. alexandri juveniles of the present study, which may reflect an adaptation of this species to the stress conditions imposed. In contrast, increases in erythrocyte counts, hemoglobin concentrations and hematocrit values soon after exposure to hypoxia are common for many fish species as a way to improve the oxygen transport capacity of blood circulation and its distribution to tissues, as found by Abdel-Tawwab et al. (2015) for Oreochromis niloticus, Aboagye and Allen (2018) for Polyodon spathula and Val et al. (2015) for Prochilodus nigricans.

Among biochemical variables, we observed a decrease in glucose concentrations at $24 \mathrm{~h}$ of hypoxia for normoxia and hypoxia treatments, compared to $48 \mathrm{~h}$ of hypoxia. This decrease may have been the result of the suspension of feeding on the day prior to the $24 \mathrm{~h}$ hypoxia sampling, which was then reestablished the following day and continued until the end of the trial. However, was observed that fish in the hypoxia treatment only returned to feeding after $24 \mathrm{~h}$ of recovery, when their glucose concentrations were similar to those of fish of the normoxia treatment at $48 \mathrm{~h}$ of recovery. This same response was also observed by Kupittayanant et al. (2011) with flowerhorn fish (Amphilophus trimaculatus x Amphilophus citrinellus $\mathrm{x}$ Vieja synspilum), for which there was a reduction in feed intake after $12 \mathrm{~h}$ of exposure to hypoxia. However, unlike our study, these authors found an increase in glucose levels with hypoxia, which is explained by the occurrence of hepatic glycogenolysis. In the present study L. alexandri juveniles submitted to hypoxia may have experienced a decrease in metabolic rate, leading to decreased feed intake and, consequently, to decreased plasma glucose concentrations. It was also observed that the restoration of food reflected an increase in triglyceride concentrations (at $48 \mathrm{~h}$ of hypoxia) in the normoxia treatment, while the hypoxia treatment did not show any significant changes.

Hypoxia conditions did not alter the plasma cholesterol concentrations of juvenile $L$. alexandri, compared to the normoxia treatment. This finding differs from other studies that found an increase or decrease in this metabolite in blood of fish also submitted to hypoxia (Bera et al. 2017; Kuppitayanant et al. 2011), feed restriction (Assis et al. 2020; Favero et al. 2019) or low water temperature (Costa et al. 2016; Favero et al. 2019; He et al. 2015) and may be related to increased energy consumption (He et al. 2015) and 
decreased synthesis of endogenous cholesterol by fish during stress situations. According to Costa et al. (2019), exposure to stressors and the intensity of stress can lead to increased plasma protein concentrations in fish, as the energy need of these animals increases under such conditions. However, hypoxia for $48 \mathrm{~h}$ was not sufficient to promote an increase in juvenile $L$. alexandri, since plasma protein concentrations did not differ significantly from fish in normoxia.

The branchial epithelium has key functions in gas exchange, such as oxygen uptake and carbon dioxide release, in addition to other important functions, such as osmoregulation, acid-base regulation, excretion of nitrogen compounds, and detoxification (Evans et al. 2005; Wilson and Laurent 2002). The present study found a reduction in primary lamella length in hypoxia and recovery periods when compared to normoxia. This reduction can be seen as a mechanism to reduce metabolic costs in ion transport (Evans et al. 2005). Some species reduce gill surface area in response to hypoxia exposure, with the intention of decreasing ion uncontrol (Matey et al. 2011; Boeck et al. 2013; Borowiec et al. 2015; Chasiotis et al. 2012).

In our study, changes in the relative proportions of gill components were also detected, such as an increase in the proportion of epithelial cells at $24 \mathrm{~h}$ of hypoxia. Epithelial cells play a key role in gas exchange and ion balance and their increase during hypoxia can be explained as a strategy to increase gas exchange and restore osmoregulatory balance (Wong and Wong 2000).

The lamellae of the secondary branches are covered by epithelial cells and pillar cells (Laurent and Dunel 1985; Takashima and Hibiya 1995). The pillar cells have contractile properties and perform blood transport for hematosis, in addition to being the first site of excretion and playing a role in ion regulation (Baldisserotto 2002). In the present study, hypoxia caused a decrease in the percentage of pillar cells, which remained so during recovery. In a study with Crucian carp (Carassius carassius), Sollid et al. (2003) found a decrease in the total amount of cells in the gills as well as an increase in the respiratory surface area, which was not observed in the present study. Also, in contrast to the present study, hypoxia was found to cause a disorganization of pillar cells in the gills of the species Hippocampus reidi (Negreiros et al. 2011).

Erythrocytes, which are responsible for transporting the oxygen molecule, had higher percentages in the first hours of recovery from hypoxia, showing that the animal was still in the process of reestablishing homeostasis and needing a rapid recruitment of erythrocytes to assist in the transport of oxygen to the gills (Inoue et al. 2011). The mucus cells present in the branchial epithelium are responsible for secreting a layer of glycoproteins and glycolipids that acts as a barrier, provides mechanical and biological protection of the epithelium (Breseghelo et. al. 2004) and facilitates ionic regulation (Diaz et al. 2000). This was evidenced in the present study by the lowest concentration being found when the animals were recovering from hypoxia, demonstrating that ionic regulation was already in the recovery phase from the stress suffered.

An increase in the percentage of chloride cells was observed at $48 \mathrm{~h}$ of hypoxia, which may indicate a compensatory response of the animals to improve ion absorption and maintain ionic and osmotic 
homeostasis in the face of the challenge of low oxygenation (Fernandes and Mazon 2003).

\section{Conclusion}

Juveniles of Lophiosilurus alexandri adapted well to hypoxia for $48 \mathrm{~h}$, as they were able to adjust most of their physiological variables to survive this stress condition and return to normoxia within $48 \mathrm{~h}$.

\section{Declarations}

\section{- Funding}

Thanks are extended Conselho Nacional de Desenvolvimento Científico e Tecnológico (CNPq-Brasil), Coordenação de Aperfeiçoamento de Pessoal de Nível Superior (CAPES-Brasil) and Fundação de Amparo à Pesquisa do Estado de Minas Gerais (FAPEMIG), for financial support and funding for the author Ronald K. Luz (CNPq - Proc. 308547 / 2018-7).

\section{-Conflicts of interest}

The authors declare that they have no known competing financial interests or personal relationships that could have appeared to influence the work reported in this paper.

\section{-Ethics approval}

This study was approved by the Animal Ethics and Welfare Committee of UFMG (protocol number: 61/2019).

\section{-Consent to participate (include appropriate statements)}

Not applicable

-Consent for publication (include appropriate statements)

Not applicable

-Availability of data and material/ Data availability

Not applicable

-Code availability (software application or custom code)

Not applicable

-Authors' contributions (include all authors): 
Lívia de Assis Porto - conception of design of experiment, conducting the experimental trial and writing of the manuscript.

Rafael Magno Costa Melo - contribution to the writing of the manuscript.

Suzane Lilian Beier - contribution to the writing of the manuscript.

Ronald Kennedy Luz - contribution to conception and design of experiment, statistical analysis and interpretation of data, writing of the manuscript and financial support for the development of the research.

Gisele Cristina Favero - contribution to conception and design of experiment, statistical analysis and interpretation of data and writing of the manuscript.

\section{References}

Abdel-Tawwab M, Hagras AE, Elbaghdady HAM, Monier, MN (2015) Effects of dissolved oxygen and fish size on Nile tilapia, Oreochromis niloticus: growth performance, whole-body composition, and innate immunity. Aquacult Int 23:1261-1274. https://doi.org/10.1007/s10499-015-9882-y

Abdel-Tawwab M, Monier MN, Hoseinifar SH, Faggio C (2019) Fish response to hypoxia stress: growth, physiological and immunological biomarkers. Fish Physiol Biochem 45:997-1013.

https://doi.org/10.1007/s10695-019-00614-9

Aboagye DL, Allen PJ (2018) Effects of acute and chronic hypoxia on acid-base regulation, hematology, ion, and osmoregulation of juvenile American paddlefish. Comp Biochem Physiol - B Biochem Mol Biol 188:77-88. https://doi.org/10.1007/s00360-017-1104-7

Araújo-Luna R, Ribeiro L, Bergheim A, Pousão-Ferreira P (2018) The impact of different rearing condition on gilthead seabream welfare: Dissolved oxygen levels and stocking densities. Aquacult Res 49:38453855. https://doi.org/10.1111/are.13851

Ashley PJ (2007) Fish welfare: current issues in aquaculture. Appl Anim Behav Sci 104:199-235. https://doi.org/10.1016/j.applanim.2006.09.001

Assis YPAS, Porto LA, Melo NFAC, Palheta GDA, Luz RK, Favero GC (2020) Feed restriction as a feeding management strategy in Colossoma macropomum juveniles under recirculating aquaculture system (RAS). Aquaculture 529:735-689. https://doi.org/10.1016/j.aquaculture.2020.735689

Baldissera MD, Souza CF, Boaventura TP, Nakayama CL, Baldisserotto B, Luz RK (2018) Purinergic signaling as a potential target of hypoxia stress-induced impairment of the immune system in freshwater catfish Lophiosilurus alexandri. Aquaculture 496:197-202. https://doi.org/10.1016/j.aquaculture.2018.07.025. 
Baldissera MD, Souza CF, Val AL, Baldisserotto B (2020) Involvement of purinergic signaling in the Amazon fish Pterygoplichthys pardalis subjected to handling stress: Relationship with immune response. Aquaculture 514:734481. https://doi.org/10.1016/j.aquaculture.2019.734481

Baldisserotto B (2002) Fisiologia de peixe aplicada à piscicultura. UFSM, Santa Maria

Barton BA (2000) Salmonid fishes differ in their cortisol and glucose responses to handling and transport stress. N Am J Aquacult 62:12-18. http://doi.org/10.1577/1548-8454(2000)0622.0.C0;2

Barton BA (2002) Stress in fishes: a diversity of responses with particular reference to changes in circulating corticosteroids. Integr Comp Biol 42:517-525. https://doi.org/10.1093/icb/42.3.517

Bera A, Sawant PB, Dasgupta S, Chadha NK, Sawant BT, Pal AK (2017) Diel cyclic hypoxia alters plasma lipid dynamics and impairs reproduction in goldfish (Carassius auratus). Fish Physiol Biochem 43:16771688. https://doi.org/10.1007/s10695-017-0401-0

Boeck G, Wood CM, Iftikar F.I, Matey V, Scott GR, Sloman, KA, Val AL (2013) Interactions between hypoxia tolerance and food deprivation in Amazonian oscars, Astronotus ocellatus. J Exp Biol 216:45904600. https://doi.org/10.1242/jeb.082891

Borowiec BG, Darcy KL, Gillette DM, Scott GR (2015) Distinct physiological strategies are used to cope with constant hypoxia and intermittent hypoxia in killifish (Fundulus heteroclitus). J Exp Biol 218:11981211. https://doi.org/10.1242/jeb.114579

Breseghelo L, Cardoso MP, Borges-de-Oliveira R, Costa MF, Barreto JCB, Sabóia-Morais SMT, Yamada AT (2004) Effects of sodium fluoride in gill epithelium of Guppy fish (Poecilia vivipara). Brazilian J Vet Res Anim Sci 41: 274-280. https://doi.org/10.1590/S1413-95962004000400009

Chasiotis H, Kolosov D, Bui P, Kelly SP (2012) Tight junctions, tight junction proteins and paracellular permeability across the gill epithelium of fishes: A review. Resp Physiol Neurobiol 184:269281. https://doi/10.1016/j.resp.2012.05.020

Cook DG, Herbert NA (2012) The physiological and behavioural response of juvenile kingfish (Seriola lalandi) differs between escapable and inescapable progressive hypoxia. J Exp Mar Biol Ecol 413:138144. https://doi.org/10.1016/j.jembe.2011.12.006

Costa DC, Mattioli CC, Silva WS, Takata R, Leme FOP, Oliveira AL, Luz RK (2016) The effect of environmental colour on the growth, metabolism, physiology and skin pigmentation of the carnivorous freshwater catfish Lophiosilurus alexandri. J Fish Biol 90:922-935. https://doi.org/10.1111/jfb.13208

Costa OTF, Dias LC, Malmann CSY, Ferreira CAL, Carmo IB, Wischneski A G, Sousa RL, Cavero BAS Lameiras, JLV, Santos MC (2019) The effects of stocking density on the hematology, plasma protein profile and immunoglobulin production of juvenile tambaqui (Colossoma macropomum) farmed in Brazil. Aquaculture 499:260-268. https://doi.org/10.1016/j.aquaculture.2018.09.040 
Diaz LS, Roa A, Garcia CB, Acero A, Navas G (2000) Length-weight relationships of demersal fishes from the upper continental slope off Colombia. ICLARM Quarterly 23:23-25.

Evans DH, Piermarini PM, Choe KP (2005) The multifunctional fish gills: dominant site for gas exchange, osmoregulation, acid-base regulation, and excretion of nitrogenous waste. Physiol Rev 85:97-177. https://doi.org/10.1152/physrev.00050.2003

Favero GC, Silva WS, Boaventura TP, Leme FOP, Luz RK (2019) Eugenol or salt to mitigate stress during the transport of juvenile Lophiosilurus alexandri, a Neotropical carnivorous freshwater catfish. Aquaculture 512: 734321. https://doi.org/10.1016/j.aquaculture.2019.734321

Fazio F, Marafioti S, Arfuso F, Piccione G, Faggio C (2013) Comparative study of the biochemical and haematological parameters of four wild Tyrrhenian fish species. Vet Med 58:576-581

Fernandes MN, Mazon AF (2003) Environmental pollution and fish gill morphology. In: Val AL, Kapoor BG (Eds) Fish Adaptations Science Publishers. Enfield, pp 203 - 231

Fitzgibbon QP, Strawbridge A, Seymour RS (2007) Metabolic scope, swimming performance and the effects of hypoxia in the mulloway, Argyrosomus japonicus (Pisces: Sciaenidae). Aquaculture 270:358368. https://doi.org/10.1016/j.aquaculture.2007.04.038

Gallo VP, Civinini, A (2003) Survey of the adrenal homolog in teleosts. In: Jeon KW (ed.) International Review of Citology. Elsevier, Oxford, pp 89-187

Gilmore KL, Doubleday ZA, Gillanders BM (2018) Testing hypoxia: physiological effects of long-term exposure in two freshwater fishes. Oecologia 186:37-47. https://doi.org/10.1007/s00442-017-3992-3

Goldenfarb PB, Bowyer FP, Hall E, Brosious E (1971) Reproducibility in the hematology laboratory: the microhematometric determination. Am J Clin Pathol 56:35-39. https://doi.org/10.1093/ajcp/56.1.35

He D, Li G, Xie H, Liu S, Luo Y (2015) Effects of feeding frequency on the post-feeding oxygen consumption and ammonia excretion of the juvenile snakehead. Tur J Fish Aquat Sci 15:293301. https://doi.org/10.4194/1303-2712-v15_2_11

Hwang PP, Lee TH, Lin LY (2011) Ion regulation in fish gills: recent progress in the cellular and molecular mechanisms. Am J Physiol Regul Integr Comp 301:28-47. https://doi.org/10.1152/ajpregu.00047

Inoue LAKA, Boijink CL, Ribeiro PT, Silva AMD, Affonso EG (2011) Avaliação de respostas metabólicas do tambaqui exposto ao eugenol em banhos anestésicos. Acta Amazonica 41:327-332.

https://doi.org/10.1590/s0044-59672011000200020

Jerez-Cepa I, Ruiz-Jarabo I, Mancera JM (2019) Bienestar animal en la acuicultura de peces: atenuación del estrés a través de la dieta y mediante el empleo de anestésicos durante el transporte. Derecho Animal (Forum of Animal Law Studies) 10:85-92. https://doi.org/10.5565/rev/da.463 
Joyce W, Gesser H, Bayley M, Wang T (2015) Anoxia and acidosis tolerance of the heart in an airbreathing fish (Pangasianodon hypophthalmus). Fish Physiol Biochem Zool 88:648-659. https://doi.org/10.1086/682701

Konkal P, Ganesh CB (2020) Exposure to hypoxia inhibits pituitary-testicular activity in the fish Oreochromis mossambicus. Aquaculture 515:734552.

https://doi.org/10.1016/j.aquaculture.2019.734552

Kupittayanant P, Kinchareon W (2011) Hematological and biochemical responses of the flowerhorn fish to hypoxia. J Anim Vet Adv 10:2631-2638. https://doi.org/10.3923/javaa.2011.2631.2638

Lai YH, Choudhary K, Cloutier SC, Xing Z, Aviran S, Tran EJ (2019) Genome-wide discovery of DEAD-box RNA helicase targets reveals RNA 2 structural remodeling in transcription termination. Genetics 212:153174. https://doi.org/10.1534/genetics.119.302058

Lankford SE, Adams TE, Cech JJ (2003) Time of day and water temperature modify the physiological stress response in green sturgeon, Acipenser medirostris. Comp Biochem Physiol - A Mol Integr Physiol 135: 291-302. https://doi.org/10.1016/s1095-6433(03)00075-8

Laurent P, Hobe H, Dunel-Erb S (1985) The role of environmental sodium chloride relative to calcium in gill morphology of freshwater salmonid fish. Cell Tissue Res 240:675-692. https://doi.org/10.1007/BF00216356

Lays N, Iversen MMT, Frantzen M, Jorgensen EH (2009) Physiological stress responses in spotted wolffish (Anarhichas minor) subjected to acute disturbance and progressive hypoxia. Aquaculture 295:126-133. https://doi.org/10.1016/j.aquaculture.2009.06.039

Li M, Qi C, Li E, Du Z, Qin JG, Chen L (2018) Metabolic response of Nile tilapia (Oreochromis niloticus) to acute and chronic hypoxia stress. Aquaculture 495:187-195.

https://doi.org/10.1016/j.aquaculture.2018.05.031

Lima LC, Ribeiro LR, Leite LR, Melo DC (2006) Estresse em peixes. R Bras Reprod Anim 30:113-117.

Long L, Zhang H, Ni Q, Liu H, Wu F, Wang X (2019) Effects of stocking density on growth, stress, and immune responses of juvenile Chinese sturgeon (Acipenser sinensis) in a recirculating aquaculture system. Comp Biochem Physiol - C Toxicol Pharmacol 219:25-34.

https://doi.org/10.1016/j.cbpc.2019.02.002

Luz RK, Santos JCE (2008) Densidade de estocagem e salinidade da água na larvicultura do pacamã. Pesqui Agropecu Bras 43:903-909. https://doi.org/10.1590/s0100-204x2008000700015

Macari M, Furlan RL, Gonzales E (1994) Fisiologia aviária aplicada a frangos de corte. FUNEP, Jaboticabal 
Magnoni LJ, Eding E, Leguen I, Prunet P, Geurden I, Ozório ROA, Schrama JW (2018) Hypoxia, but not an electrolyte-imbalanced diet, reduces feed intake, growth and oxygen consumption in rainbow trout (Oncorhynchus mykiss). Scientific Reports 8:4965. https://doi.org/10.1038/s41598-018-23352-z

Mahfouz ME, Sherif AH (2015) A multiparameter investigation into adverse effects of aflatoxin on Oreochromis niloticus health status. J Basic Appl Zool 71:4859. https://doi.org/10.1016/j.jobaz.2015.04.008

Matey V, Iftikar FI, De Boeck G, Scott GR, Sloman KA, Almeida-Val VMF, Wood C M (2011) Gill morphology and acute hypoxia: responses of mitochondria-rich, pavement, and mucous cells in the Amazonian oscar (Astronotus ocellatus) and the rainbow trout (Oncorhynchus mykiss), two species with very different approaches to the osmo-respiratory compromise. Can J Zool 89:307-324. https://doi/10.1139/z11-002

Mattioli CC, Takata R, Leme FOP, Costa DC, Luz RK (2019) Physiological and metabolic responses of juvenile Lophiosilurus alexandri catfish to air exposure. Fish Physiol Biochem 45:455-467. https://doi.org/10.1007/s10695-018-0576-z

Moreira AGL, Faria WRL (2015) Uso do óleo de cravo na simulação de transporte de juvenis de tilápia do Nilo. Conex Ci e Tecnol 9:85-92. https://doi.org/10.21439/conexoes.v9i3.827

Negreiros, LA, Silva BF, Paulino MG, Fernandes MN, Chippari-Gomes AR (2011) Effects of hypoxia and petroleum on the genotoxic and morphological parameters of Hippocampus reidi. Comp Biochem Physiol, Part C: Toxicol Pharmacol 153:408-414. https://doi.org/10.1016/j.cbpc.2011.02.001

Refaey MM, Li D, Tian X, Zhang Z, Zhang X, Li L, Tang R (2018) High stocking density alters growth performance, blood biochemistry, intestinal histology, and muscle quality of channel catfish Ictalurus punctatus. Aquaculture 492:73-81. https://doi.org/10.1016/j.aquaculture.2018.04.003

Richards JG (2009) Metabolic and molecular responses of fish to hypoxia. Fish Physiol 27:443485. https://doi.org/10.1016/s1546-5098(08)00010-1

Schreck CB (2010) Stress and fish reproduction: The roles of allostasis and hormesis. Gen Comp Endocrinol 165:549-556. https://doi.org/10.1016/j.ygcen.2009.07.004

Schreck CB, Tort L (2016) The concept of stress in fish. Fish Physiol 35:1-34.

https://doi.org/10.1016/b978-0-12-802728-8.00001-1

Sena AC, Teixeira RR, Ferreira EL, Heinzmann BM, Baldisserotto B, Caron BO, Schmidt D, Couto RD, Copatti CE (2016) Essential oil from Lippia alba has anaesthetic activity and is effective in reducing handling and transport stress in tambacu (Piaractus mesopotamicus $\times$ Colossoma macropomum). Aquaculture 465:374-379. https://doi.org/10.1016/j.aquaculture.2016.09.033

Shibata OA (2003) Family Pseudopimelodidae. In: Reis, R.E., Kullander, S.O, Ferrars Junior CJ (Eds.). Check list of the freshwater fishes of South and Central America, Porto Alegre, pp 401-405 
Sollid J, De Angelis P, Gundersen K, Nilsson G (2003) Hypoxia induced adaptive and reversible gross morphological changes in crucian carp gills. J Exp Biol 206:3667-3673.

https://doi.org/10.1242/jeb.00594

Takashima F, Hibiya T (1995) An atlas of fish histology: normal and pathological features (2ed) Fischer Verlag, Tokyo, pp 195

Travassos H (1959) Nótula sobre o pacamã Lophiosilurus alexandri Steindachner, 1876. Atlas da Sociedade de Biologia 4:1-2.

Val AL, Gomes KRM, Almeida-Val VMF (2015) Rapid regulation of blood parameters under acute hypoxia in the Amazonian fish Prochilodus nigricans. Comp Biochem Physiol - A Mol Integr Physiol 184:125-131. https://doi.org/10.1016/j.cbpa.2015.02.020

Wendelaar Bonga SE (1997) The stress response in fish. Physiol Rev 77:591-625.

https://doi.org/10.1152/physrev.1997.77.3.591

Wilson JM, Laurent P (2002) Fish gill morphology: inside out. J Exp Zool 293:192-213.

https://doi.org/10.1002/jez.10124

Wong CKC, Wong MH (2000) Morphological and biochemical changes in the gills of tilapia (Oreochromis mossambicus) to ambient cadmium exposure. Aquat Toxicol 48:517-

527. https://doi.org/10.1016/s0166-445x(99)00060-0

Xiao W (2015) The hypoxia signaling pathway and hypoxic adaptation in fishes. Sci China: Life Sci 58:148-155. https://doi.org/10.1007/s11427-015-4801-z

Yang S, Yan T, Wu H, Xiao Q, Fu HM, Luo J, Li SJ (2017) Acute hypoxic stress: Effect on blood parameters, antioxidant enzymes, and expression of HIF-1alpha and GLUT-1 genes in largemouth bass (Micropterus salmoides). Fish Shellfish Immunol 67:449-458. https://doi.org/10.1016/j.fsi.2017.06.035

Yarahmadi P, Miandare HK, Fayaz S, Caipang CMA (2016) Increased stocking density causes changes in expression of selected stress- and immune-related genes, humoral innate immune parameters and stress responses of rainbow trout (Oncorhynchus mykiss). Fish Shellfish Immunol 48:43-53. https://doi.org/:10.1016/j.fsi.2015.11.007

Zhang CN, Li XF, Tian HY, Zhang DD, Jiang GZ, Lu KL, Liu WB (2015) Effects of fructooligosaccharide on immune response, antioxidant capability and HSP70 and HSP90 expressions of blunt snout bream (Megalobrama amblycephala) under high ammonia stress. Fish Physiol Biochem 41:203-217. https://doi.org/10.1007/s10695-014-0017-6

\section{Figures}



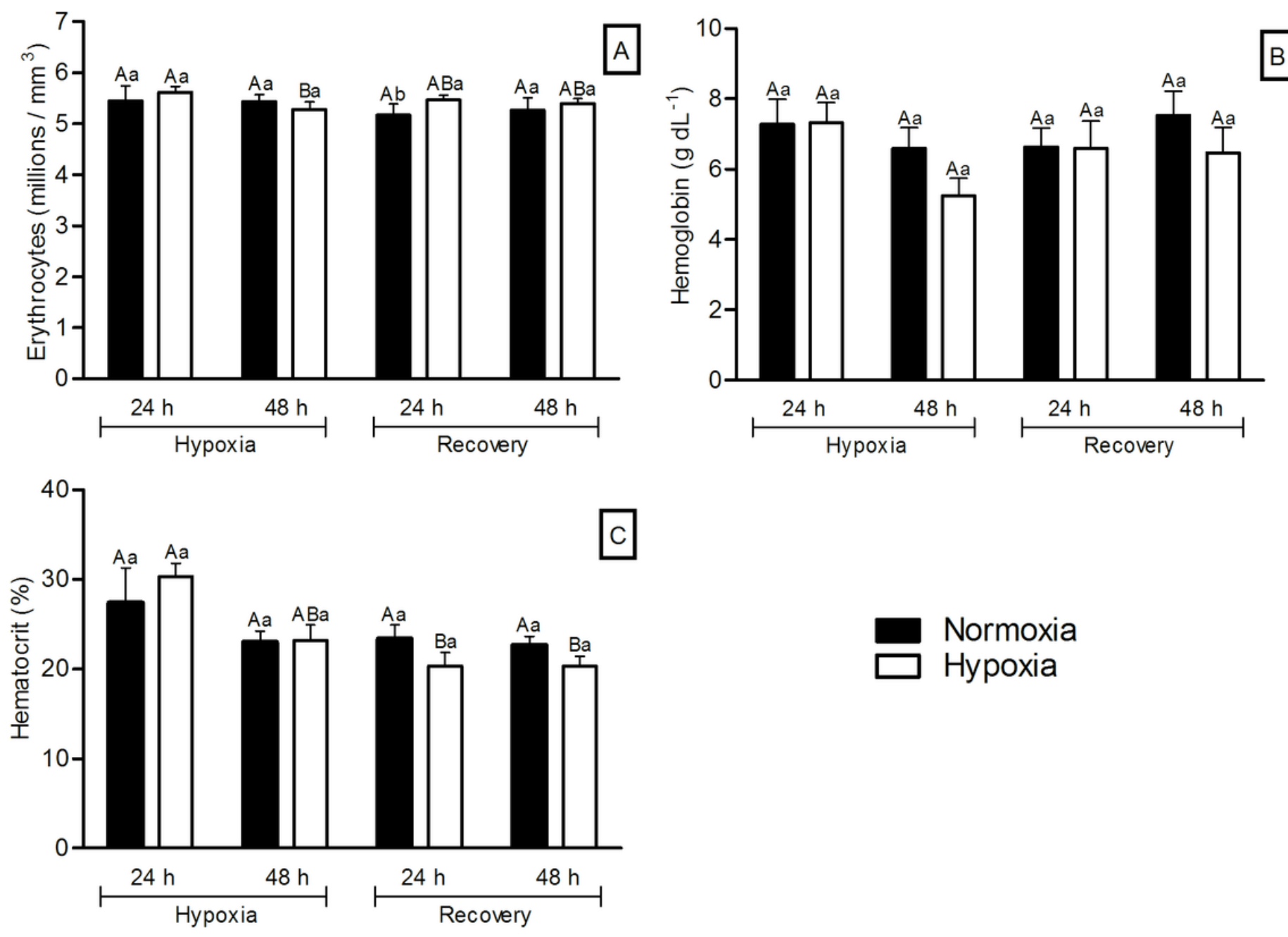

Normoxia

$\square$ Hypoxia

\section{Figure 1}

Erythrocytes (A), hemoglobin (B) and hematocrit (C) for L. alexandri juveniles subjected to hypoxia (for 48 h) and recovery (for $48 \mathrm{~h}$ ). Capital letters indicate significant differences between normoxia or hypoxia treatment over the sampling time. Lowercase letters compare normoxia and hypoxia treatments within the same sampling time. Values are expressed as means \pm standard error (SE). All comparisons were statistically different at $\mathrm{P}<0.05$. 

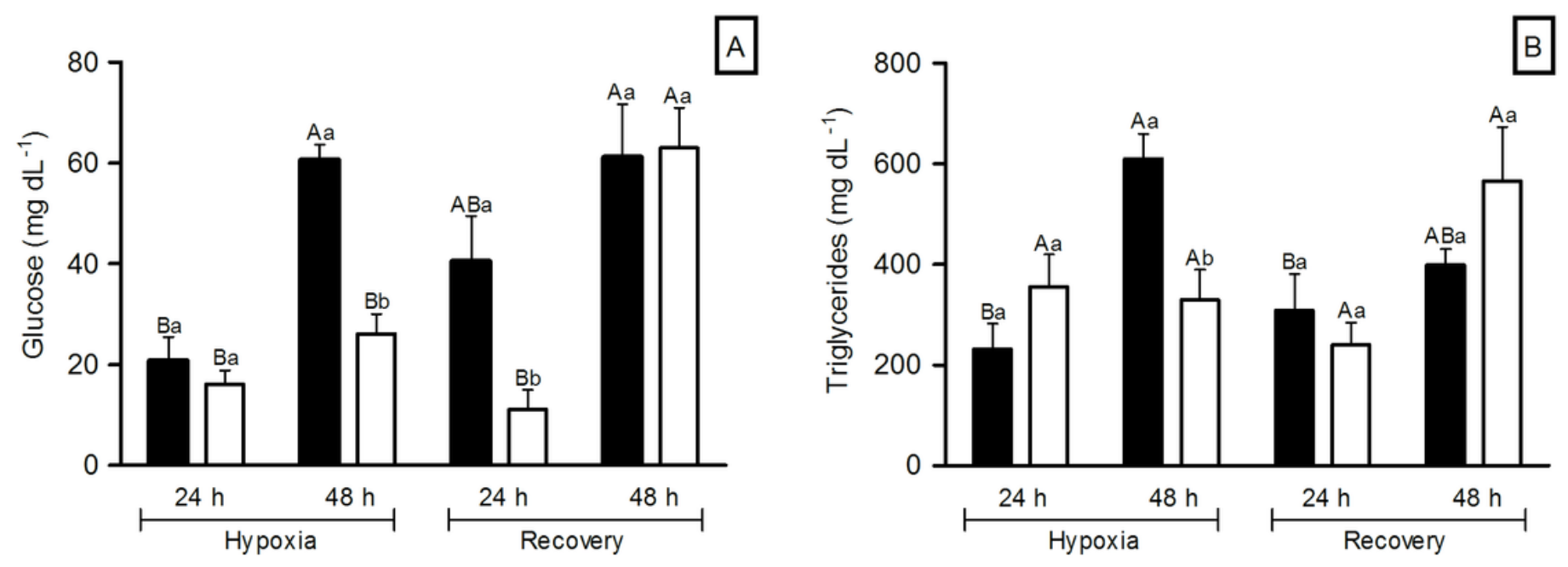

Normoxia

Hypoxia
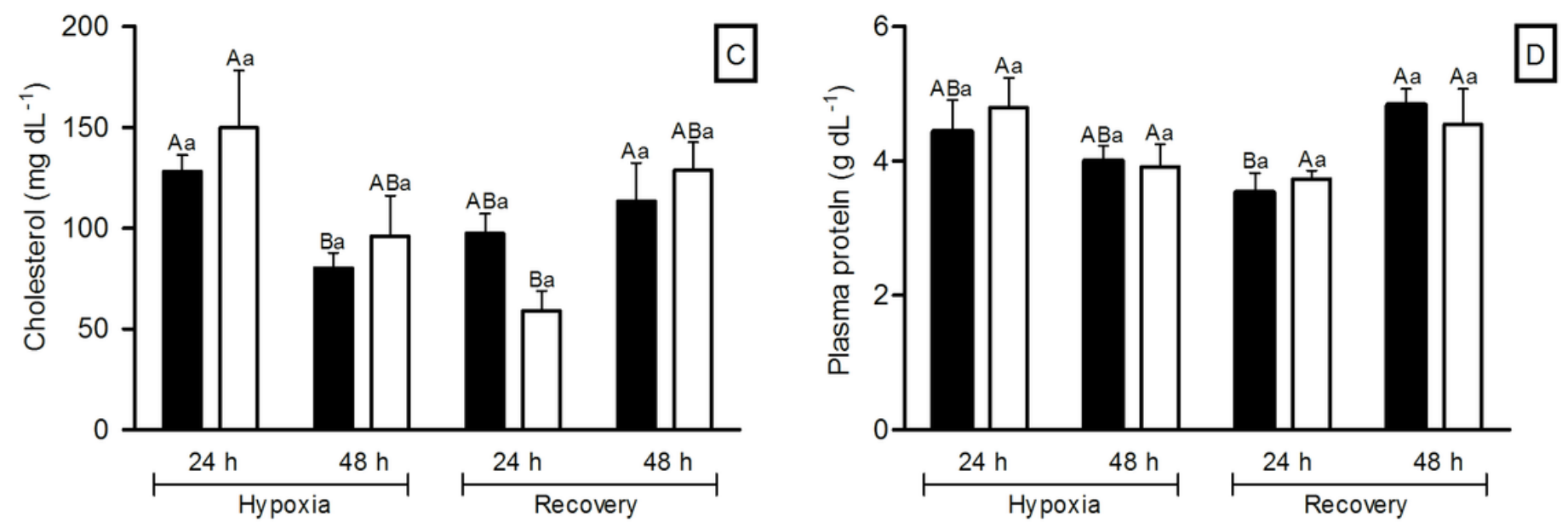

Figure 2

Glucose (A), triglycerides (B), cholesterol (C) and plasma protein (D) for L. alexandri juveniles subjected to hypoxia (for $48 \mathrm{~h}$ ) and recovery (for $48 \mathrm{~h}$ ). Capital letters indicate significant differences between normoxia or hypoxia treatment over the sampling time. Lowercase letters compare normoxia and hypoxia treatments within the same sampling time. Values are expressed as means \pm standard error (SE). All comparisons were statistically different at $\mathrm{P}<0.05$. 


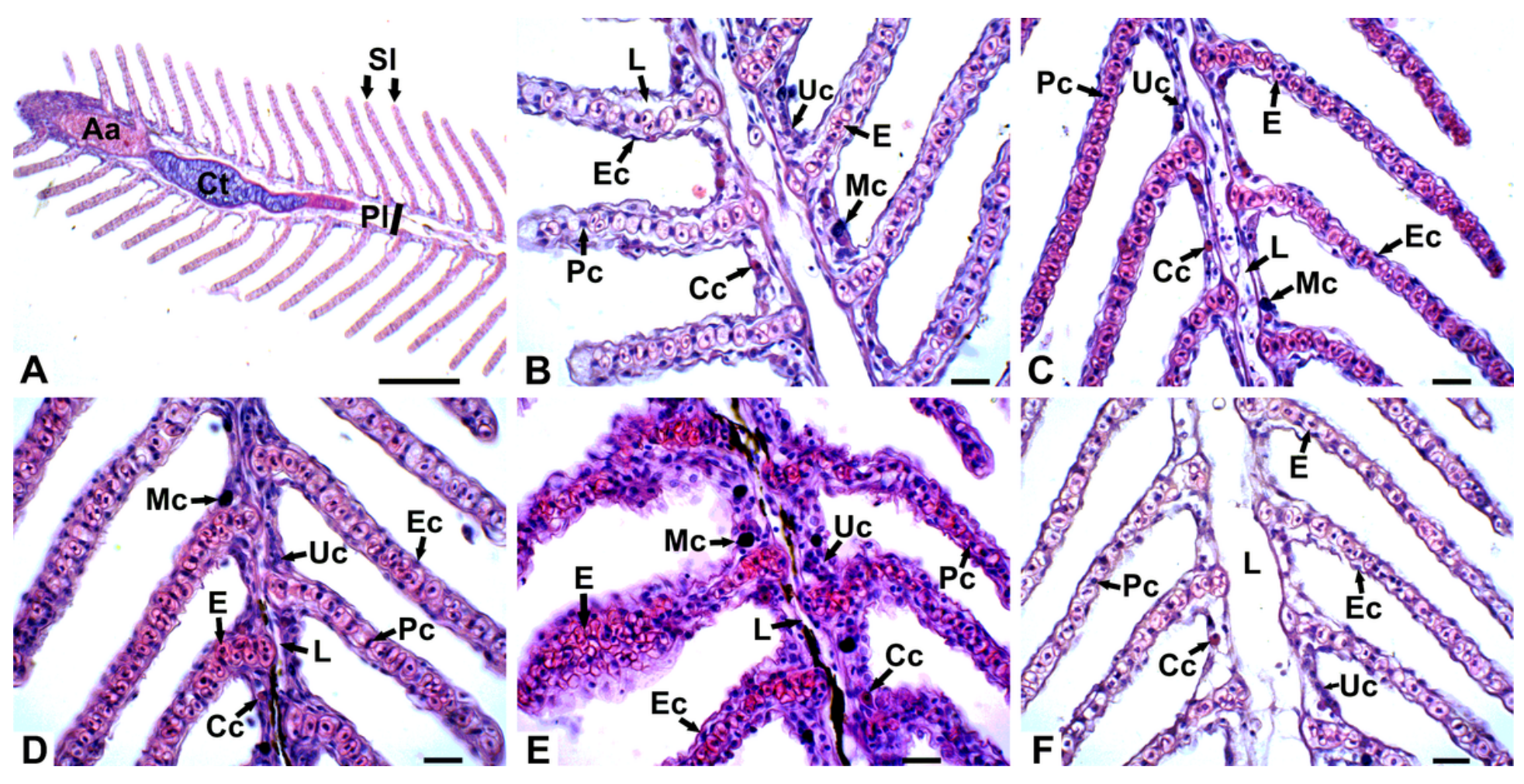

Figure 3

Longitudinal histological sections, stained with hematoxylin-eosin, of gills of juveniles of L. alexandri submitted to hypoxia. Overview of the branchial filament containing primary (PI) and secondary (SI) lamellae, central support of cartilaginous tissue (Ct) and afferent arteriole (Aa) (A); Normoxia treatment (B); Hypoxia treatment at $24 \mathrm{~h}$ of hypoxia (C); Hypoxia treatment at $48 \mathrm{~h}$ of hypoxia (D); Hypoxia treatment at $24 \mathrm{~h}$ of recovery $(\mathrm{E})$; Hypoxia treatment at $48 \mathrm{~h}$ of recovery $(\mathrm{F})$. Ec, Epithelial cell; $\mathrm{E}$, Erythrocyte; Mc, Mucous cell; L, Lumen of blood capillary; Cc, Chloride cell; Pc, Pillar cell; Uc, Undifferentiated cell. Scale bars: $A=100 \mu \mathrm{m}, B-F=50 \mu \mathrm{m}$. 